\title{
Elevation of the Salvage Synthesis of Ribonucleic Acid in the Rat Liver during the Induction of Hepatoma with 3'-Methyl-4-(dimethylamino) azobenzene
}

\author{
Osamu Tamemasa, Masakatsu TezuKa, Munetoshi \\ FUJISAWA and Takayuki TAKEDA \\ Laboratory of Radiobiochemistry, Shizuoka College of Pharmacy \\ Oshika 2-2-1, Shizuoka-shi 422 \\ Received May 4, 1978
}

\begin{abstract}
Incorporation of uracil and orotic acid into the ribonucleic acid (RNA) fraction of rat liver during carcinogenesis induced with $3^{\prime}$-methyl-4-(dimethylamino)azobenzene was investigated. Uracil incorporation was found to be gradually elevated during the early stage (about 2 weeks) of the carcinogenesis, although not in the normal rat liver homogenates contacted with the carcinogen for a short hours, and the elevated uptake was maintained until tumor induction. On the other hand, orotic acid incorporation reverted to the original level after a temporary increase during the early stage.

In a good agreement with the increased uracil incorporation, activities of both uridine phosphorylase and uridine kinase involved in the salvage pathway of RNA synthesis also increased during the early stage, and their activities in the liver were maintained at elevated levels after discontinuance of the carcinogen feeding. The activity of uridine monophosphate (UMP) pyrophosphorylase, converting uracil to UMP, was not detected during the early stage.

Significance of the activation of the salvage pathway of RNA synthesis during the early stage of an azo dye-induced carcinogenesis were discussed.
\end{abstract}

\section{Introduction}

Uracil and uridine are actively incorporated for the synthesis of ribonucleic acid (RNA) in certain cancer (cells ${ }^{1) \sim 6)}$. This increased uridine utilization in rat hepatoma induced with $3^{\prime}$-methyl-4-(dimethylamino) azobenzene (3'-Me-DAB) was due to increased uridine kinase activity $\left.{ }^{710}\right)$ and not to increased RNA polymerase activity ${ }^{10}$. The high utilization was also demonstrated in precancerous rat liver during feeding of the same carcinogen $^{\text {7) a) }}$.

Our previous paper ${ }^{\text {s) }}$ reported that animal cells of several kinds including certain cancer cells showed a high incorporation activity for uridine and uracil. There was a good parallelism between the high incorporation activity and the increased activities of both the kinase (EC 2.7.1.48) and phosphorylase (EC 2.4.2.3) for uridine in these cells.

It was shown by Reid" that, in the early stage within 5-41 days af ter the azo-dye feeding, uridine phosphorylase activity decreased slightly $(-8 \pm 7.1 \%)$, contrary to a marked increase $(53 \pm 14.7 \%)$ in uridine kinase activity.

The present paper describes the changes in the incorporation of uracil and orotic acid, and of the activities of uridine phosphorylase, uridine kinase, and uridine monophosphate (UMP) pyrophosphorylase (EC 2.4.2.9) in the rat liver during the induction of hepatoma by oral administration of $3^{\prime}$-Me-DAB, and it was demonstrated that both activities except the pyrophosphorylase were elevated in an early stage of hepatoma induction with this carcinogen.

\section{Materials and Methods}

2.1 Chemicals

Uracil[ $\left.2{ }^{14} \mathrm{C}\right](21.0 \mathrm{mCi} / \mathrm{mmol})$ and orotic $\operatorname{acid}\left[6{ }^{-14} \mathrm{C}\right](20.6 \mathrm{mCi} / \mathrm{mmol})$, and uridine $\left[2{ }^{-14} \mathrm{C}\right]$ $(58.0 \mathrm{mCi} / \mathrm{mmol})$ were purchased from the Dai- 
ichi Pure Chemicals Co., Tokyo, and the Radiochemical Centre, Amersham, England, respectively. Radiochemical purity of these precursors was checked by paper or thin-layer chromatography before use.

Other biochemical reagents were products of the Sigma Chemical Co., U.S.A.

\subsection{Cells and tissues}

Ehrlich mouse ascites tumor cells were collected in the same manner as described in a previous paper ${ }^{6)}$, and suspended in Locke's solution. Liver was obtained from rats of ca. 200-g male Wistar strain fed on a diet containing $0.06 \% 3^{\prime}$ Me-DAB in pellets for a given period. The hepatoma formation was ascertained with the naked eye. The rats were stunned, decapitated, and the liver was perfused through the hepatic vein with ice-cold Locke's solution. The pooled liver removed from 3 rats in a group was then

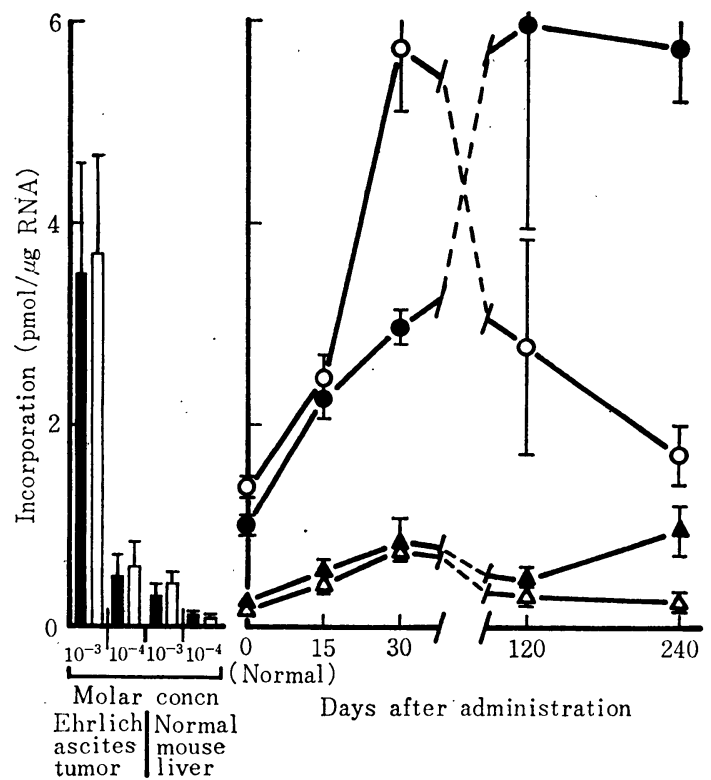

Fig. 1 Incorporation of uracil[ $\left[2^{-14} \mathrm{C}\right]$ or orotic $\left[6^{-14} \mathrm{C}\right]$ acid into RNA in the liver of rats administered $3^{\prime}$-Me-DAB.

The cells were incubated with each of ${ }^{14} \mathrm{C}$-labeled precursors at $37^{\circ}$ for $60 \mathrm{~min}$, and RNA fractions were prepared.

Data of Ehrlich mouse ascites tumor and normal mouse liver are presented for comparison.

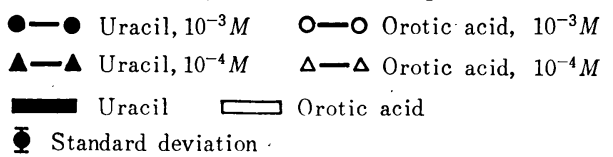

gently homogenized in a Potter's glass homogenizer, sieved in a similar manner as described by Kaltenbach, ${ }^{11)}$ and finally suspended in Locke's solution.

2.3 In vitro incorporation of radioactive precursors into RNA

Incubation of the cells or sieved liver with a labeled material and preparation of RNA fractions were performed in the same manner as described in our previous paper ${ }^{6)}$. The incubation was made in triplicates.

\subsection{Assay of enzyme activity}

Uridine phosphorylase and uridine kinase were assayed as described elsewhere $\left.{ }^{6}\right)$. UMP pyrophosphorylase was assayed according to the conventional method described by Reichard and Skסld ${ }^{12)}$.

\section{Results}

3.1. In vitro incorporation of uracil[ $\left[{ }^{-14} \mathrm{C}\right]$ and orotic $\operatorname{acid}\left[6-{ }^{14} \mathrm{C}\right]$ into rat liver RNA during administration of $3^{\prime}$ Me-DAB

Changes in the incorporation activity after administration of $3^{\prime}$-Me-DAB are illustrated in Fig. 1. The increased incorporation of both precursors was observed already after 15 days and, later, the orotic acid incorporation was restored to a nearly original level after 240 days at the latest, following a step rise around 30 days later. On the other hand, uracil incorporation followed a gentle upward slope towards the 30- day level, were brought to a markedly high level after administration for around 120 days, and later maintained at the elevated value. Such a characteristic change of these precursors incorporation was not observed in their $10^{-4} M$ concentrations, perhaps owing to the influence of the endogenous precursors.

Since, as will be discussed later, several biochemical changes have been detected in the early stage of carcinogenesis induced by 3'-Me-DAB, whether or not the elevation of the precursor incorporation was seen in rat liver after a few days of administration 
or in vitro short hour contact of liver homogenates with the carcinogen was examined. No increased incorporation was seen in rat liver 40 $\mathrm{hr}$ after intraperitoneal injection of a single dose ( $200 \mathrm{mg} / \mathrm{kg}$ body weight) of the carcinogen suspended in $1 \mathrm{~m} l$ of $0.5 \%$ carboxymethylcellulose-containing physiological saline, and in the normal rat liver homogenate incubated at $37^{\circ}$ for $1 \mathrm{hr}$ at $10^{-3} M$ concentration of the carcinogen dissolved in $1 \%$ dimethyl sulfoxide- containing Locke's solution, or in the same incubation after preincubation with the carcinogen at $37^{\circ}$ for $6 \mathrm{hr}$.

A noncarcinogen, 2-methyl-4-(dimethylamino) azobenzene, orally administered did not exhibit such an elevated incorporation pattern of uracil and orotic acid.

3.2 Activity of uridine phosphorylase, uridine kinase, and UMP pyrophosphorylase in the rat liver during administration of 3'-Me-DAB

The first two enzyme activities were markedly enhanced in an early stage of the tumor induction (Figs. 2 and 3), with a good parallelism to the elevated uracil incorporation. The increased phosphorylase activity of the liver of a rat which received the carcinogen for 30 days decreased to a certain extent by the subsequent feeding of a normal diet for 60 days (Fig. 2), while the high kinase activity mobilized by the

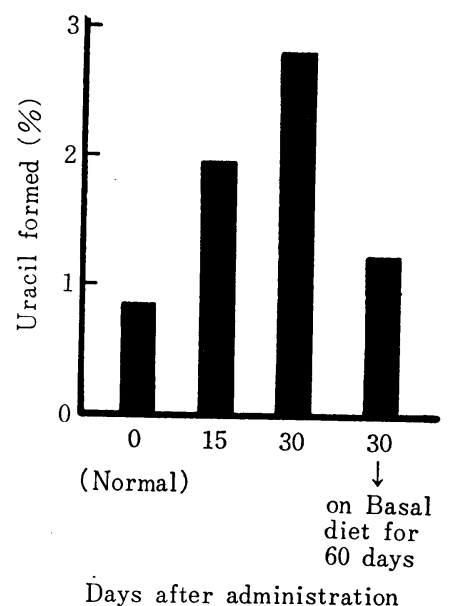

Fig. 2 Activity of uridine phosphorylase in the extract of the liver of rats administered $3^{\prime}$-Me-DAB.

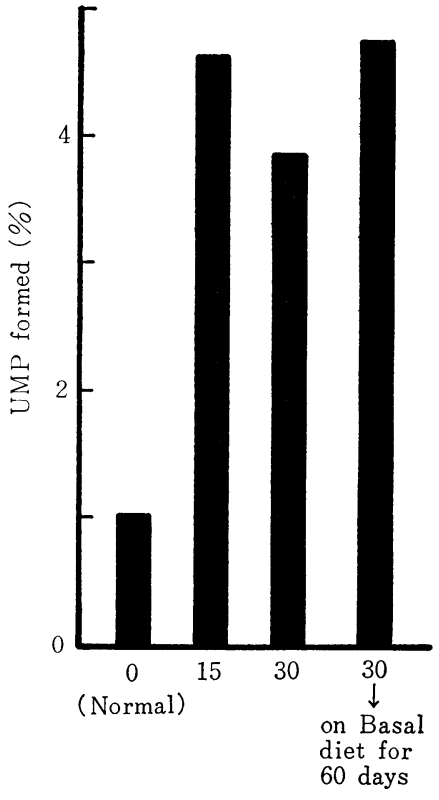

Days after administration

Fig. 3 Activity of uridine kinase in the extract of the liver of rats administered $3^{\prime}-\mathrm{Me}^{-}$ DAB.

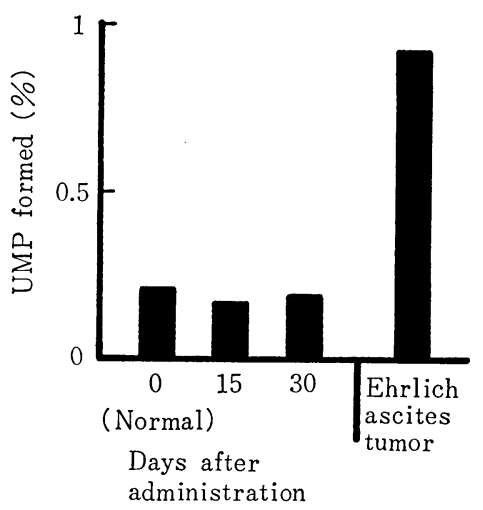

Fig. 4 Activity of UMP pyrophosphorylase in the extract of the liver of rats administered $3^{\prime}-\mathrm{Me}-\mathrm{DAB}$ and in Ehrlich mouse ascites tumor.

Three $\mathrm{m} l$ of phosphate buffer $(\mathrm{pH} 7.4)$ extract prepared from 200-mg acetonedried powder of liver homogenates was incubated with $1 \mathrm{ml}$ of a solution containing $10 \mu \mathrm{mol}$ uracil $\left[22^{-14} \mathrm{C}\right], 20 \mu \mathrm{mol}$ ATP, $40 \mu \mathrm{mol}$ ribose-5-phosphate, 60 $\mu \mathrm{mol}$ phosphoglyceric acid, and $75 \mu \mathrm{mol}$ $\mathrm{MgCl}_{2}$ at $37^{\circ}$ for $30 \mathrm{~min}$. After the reaction was stopped by heating at $100^{\circ}$ for $2 \mathrm{~min}$, the mixture was centrifuged. UMP held back in the supernatant was collected through a column $(1 \times 20 \mathrm{~cm})$ of AG-1×2 ion exchange resin (formate form). 
carcinogen had been maintained up to the days (Fig.3) under the same conditioning of feeding. UMP pyrophosphorylase activity of the rat liver was not elevated after 30-day administration of 3'-Me-DAB (Fig. 4), although the activity was detected in Ehrlich mouse ascites tumor cells tested for comparison.

\section{Discussion}

The present results indicate that an increased incorporation of uracil was detected during the early stage of hepatoma induction (Fig. 1), and that, with a good agreement with a previous result $^{\text {t) }}$ that cancers showing a high incorporation for uridine and uracil also indicated high activities of both uridine phosphorylase and uridine kinase, both the enzymic activities rose with the elevation of uracil incorporation during the early stage of carcinogenesis. Although the relative amount of endogenous uridine and orotic acid should be important in determining the incorporation of exogenous precursors, there is no clear demonstration of difference in the content of these precursors between in tumor cells and normal liver ${ }^{10}$.

It is particularly interesting that noncarcinogenic 2-methyl-4-(dimethylamino) azobenzene, ${ }^{13)}$ a 3'-Me-DAB analog, caused no increased incorporation for uracil during its administration.

In addition to that the increased incorporation of uracil and uridine into cancer cell RNA was due to the blocking of a serial catabolic route of uracil or uridine to $\beta$-alanine in cancer cells, $^{2)},{ }^{3)}$ the results of previous ${ }^{\text {s) }}$ and present studies supported the elevation of enzyme activities involved in the successive synthesis of uridine mononucleotide from uracil and uridine, as has already been pointed out by other investigators. ${ }^{\text {) } ~ 10)}$

Appearance of a number of proteins or enzymes during the early stage of chemical carcinogenesis, such as enzyme induction, ${ }^{14)}$-18) specific protein production, ${ }^{17) ~}{ }^{211}$ isoenzymic pattern alteration, ${ }^{22)}$,23) etc., have already been reported.

An autoradiographic study24) on the RNA synthesis in hyperbasophilic and basophilic cells of azo dye-produced "preneoplastic" liver after ${ }^{3} \mathrm{H}$-uridine injection demonstrated that RNA synthesis in the hyperbasophilic cells was 70\% higher than the basophilic cells and 50\% greater than the liver parenchyma of the control rats ${ }^{25}$. It seems that this autoradiographic study provided an important evidence that the increased activities of both the phosphorylase and kinase were due to the increased net synthesis of the enzyme proteins involved in the salvage pathway, as might be expected from isoenzyme pattern change and specific protein production. Persistence of the increased activity of uridine phosphorylase and uridine kinase after discontinuance of carcinogen feeding (Figs. 2 and 3) may resemble the findings that tumor induction was observed after the administration of a submanifestational dose of $3^{\prime}$-Me-DAB, which was followed by no carcinogen feeding, and then a subsequent administration of the same dose after a 12-week interval, ${ }^{26)}$ or also after similar administration of two different carcinogens affecting the same target organ ${ }^{27)}$.

Enhanced synthesis of UMP via uridine kinase reaction might inhibit the formation of UMP via orotidylic acid decarboxylase reaction, resulting in a greater utilization of uridine for RNA synthesis than orotic acid.

Although only an increase of uridine kinase of the salvage pathway during 3'-Me-DAB carcinogenesis was pointed out by the past investigators, ${ }^{\text {() }}$ (9) the increased activity of not only uridine kinase but also uridine phosphorylase was demonstrated in the present study. This discrepancy may be due to a difference in the pool levels of endogenous uracil in precancerous liver of azo dye-fed rats.

The authors express their gratitude to $\mathrm{Mr}$. T. Kose and Mr. Y. Suzuki of senior students in this laboratory for their technical assistance.

\section{References}

1) A. Cantarow, K.E. Paschkis, T.L. Williams: Biochem. Biophys. Res. Commun., 1, 75-78 (1959)

2) C. Heidelberger, K.C. Leibman, E. Harbers, P.M. Bhargava: Cancer Res., 17, 399-404 (1957)

3) R.J. Rutman, A. Cantarow, E.K. Paschkis: ibid., 14, 119-34 (1954)

4) M. Schreiber, G. Schreiber, J. Kartenbeck: 
ibid., 34, 2143-50 (1974)

5) O. Tamemasa, S. Okada, K. Yui: Abstr. 156th Natl. Meet. Am. Chem., Soc. Biol., 236 (1968)

6) M. Tezuka, O. Tamemasa: Gann, 68, 28792 (1977)

7) E. Reid: Nature, 194, 1153-56 (1962)

8) E. Reid: Cancer Res., 22, 398-430 (1962)

9) J.T. Nodes, E. Reid: Br. J. Cancer, 17, 745-74 (1963)

10) H. Matsudaira, C. Nakamura, T. Hishizawa: Gann, 59, 61-71 (1968)

11) J.P. Kaltenbach: Fed. Proc., 11, 237-38 (1952)

12) P. Reichard, O. Sköld: Acta Chem. Scand., 11, 17-23 (1957)

13) G.P. Warwick: Eur. J. Cancer, 3, 227-33 (1967)

14) H.V. Gelboin: Adv. Cancer Res., 10, 1-81 (1967)

15) A. Kaneko, K. Dempo, T. Iwasaki, T. Onoe: Gann, 63, 31-39 (1972)
16) A. Kaneko, K. Dempo, T. Iwasaki, T. Onoe: ibid., 63, 40-48 (1972)

17) F.F. Becker, A.A. Horland, A. Shurgin, S. Sell: Cancer Res., 35, 1510-13 (1975)

18). K. Dempo, N. Chisaka, Y. Yoshida, A. Kaneko, T. Onoe: ibid., 35, 1282-87(1975)

19) T. Kitagawa, T. Yokochi, H. Sugano: Int. J. Cancer, 10, 368-81 (1972)

20) R. Kores, G.S. Williams, J. Weisburger: Cancer Res., 33, 613-17 (1973)

21) H. Watabe: ibid., 31, 441-49 (1971)

22) H. Endo, M. Eguchi, Y. Yanagi: ibid., 30, 743-52 (1970)

23) A. Kaneko, K. Dempo, Y. Yoshida, N. Chisaka, T. Onoe: ibid., 34, 1816-21(1974)

24) E.L. Opie: J. Exp. Med., 84, 91-106(1946)

25) M.R. Banerjee, R.S. Yamamoto: Cancer Res., 28, 455-61 (1968)

26) C. C. Clayton, C. A. Bauman: ibid., 9, 575-82 (1949)

27) W. Nakahara, F. Fukuoka: Gann, 51, 125-37 (1960)

要旨

\title{
3'-メチル DAB 投与によるラット肝 RNA 合成の Salvage 経路活性の上昇
}

\author{
為政 脩，手塚雅勝，藤沢宗駿，武田隆幸 \\ 静岡薬科大学放射薬品学教室 \\ 422 静岡市小鹿2-2-1
}

発がん物質の $3^{\prime}$-メチル DAB をラットに投与し，その経過日数と肝 RNA ヘのウラシル。オ ロチン酸のとりこみ活性の変化を検討するとともに，投与初期に打ける RNA 合成の Salvage 系 に働く䣼素活性の変動を検討した。

ウラシル $\left(10^{-3} M\right)$ の肝 RNA へのとりこみは $3^{\prime}$-メチル DAB 投与15日後から明らかに増大 し，肝がんが形成された 240 日後までその活性増大は持続した。一方，オロチン酸のとりこみは投 与後15〜30日で増大したが，240日後には正常のレベルにもどった。

RNA 合成の Salvage 経路に作用する醭素の 万ち, ウリジンフォスフォリラーゼ拈よびウリジン キナーゼは投与後15〜30日で活性が上昇したが，UMP ピロフォスフォリラーゼ活性の上昇は認め られなかった。また，ウリシシンキナーセとウリジンフォスフォリラーゼの活性は，3'-メチル DAB を30日間投与したのち正常食にして60日間飼育したラット肝においても，高いままで維持された。

このよらな発がんの初期過程における RNA 合成の Salvage 経路活性の上昇と, それに働く醉 素活性の上昇との関連について考察した。 